\title{
DUKUNGAN KELUARGA PADA ORANG DENGAN GANGGUAN JIWA YANG DI PASUNG DI KECAMATAN MANGANITU
}

\author{
FAMILY SUPPORTING TO PRISONER WITH MENTAL DISORDER \\ IN MANGANITU SUBDISTRICT
}

\author{
Maryati Tatangindatu, Nansy Pangandaheng \\ Keperawatan, namaPoliteknik Negeri Nusa Utara \\ Email: mtatangindatu@gmail.com
}

\begin{abstract}
Abstrak: Merawat anggota keluarga yang mengalami gangguan jiwa merupakan tanggung jawab keluarga selama pasien tinggal bersama keluarga. Merawat orang yang mengalami gangguan jiwa bukanlah hal yang mudah terutama jika pasien tidak bisa diatur. Keluarga harus memiliki kesabaran yang tinggi merawat pasien gangguan jiwa, apalagi pelayanan kesehatan jiwa di daerah perbatasan sulit dijangkau. Bagi keluarga tindakan pemasungan merupakan salah satu cara yang aman untuk menghindari konflik dengan lingkungan sekitar. Menguraikan dukungan keluarga pada orang dengan gangguan jiwa yang di pasung di Kecamatan Manganitu Kabupaten Kepulauan Sangihe. Tujuan penelitian ini yaitu untuk menguraikan dukungan keluarga terhadap pasien gangguan jiwa yang di Pasung. Metode: Penelitian menggunakan desain kualitatif fenomenologi. Waktu dan tempat penelitian yaitu penelitian ini dilakukan di Kecamatan Manganitu pada bulan September 2019. Penelitian ini yang menjadi informan adalah anggota keluarga yang memiliki klien gangguan jiwa dipasung sebanyak 3 informan. Wawancara mendalam semi terstruktur dilakukan untuk menggali data tentang dukungan keluarga. Penelitian ini ditemukan tiga tema besar dalam penelitian ini. Pertama, Gejala gangguan jiwa, kedua penyebab pemasungan dan yang ketiga dukungan keluarga. Kesimpulan penelitian ini yaitu gangguan jiwa tidak bisa disembuhkan secara total dengan jangka waktu yang pendek akan tetapi bisa mengurangi kekambuhan tanpa harus dipasung. Dukungan keluarga bisa diberikan dalam bentuk perhatian, kasih sayang, doa dan empati. Kesembuhan klien yang mengalami gangguan jiwa bergantung pada keluarga terutama dalam memenuhi kebutuhan klien setiap hari. Tanpa dukungan keluarga maka kekambuhan mudah terjadi kepada klien dengan gangguan jiwa.
\end{abstract}

Kata kunci: Dukungan keluarga, Pasung, Gangguan jiwa, Manganitu/Sangihe

\begin{abstract}
Abtract: Caring for family members with mental disorders was the responsibility of the family as long as the patient live with the family. Caring for people with mental disorders is not easy, especially if the patient cannot be managed. Families must have high patience in caring for mental patients, especially mental health services in border area those were difficult to find. For family, the act of shackling was a safe way to avoid conflict with the surrounding environment. Describes family support to people with mental disorders who were live in Manganitu Subdistrict, Sangihe Islands Regency. The purpose of this study was to describe Family Supporting To Prisoner With Mental Disorder, Method was used a phenomenological qualitative design. Time and place of those reaseach was conducted in Manganitu District in September 2019. Those research, which became the informants were three (3) family members who had mental disorders. Semi-structured in-depth interviews were conducted to explore data on family support. Those study found three major themes in this study. First, symptoms of mental disorders, secondly the cause of shackling and the third was family support. The conclusion of this study is mental disorders cannot be completely cured in a short period of time but can reduce recurrence without having to be shackled. Family support can be given in the form of attention, compassion, prayer and empathy. The healing of patient with mental disorders depends on the family, especially the needs of patient every day. Without family support, frecurrence was easy for clients with mental disorders.
\end{abstract}

Keywords: Family support, prison, mental disorders, Manganitu / Sangihe 


\section{PENDAHULUAN}

Memiliki dan merawat orang yang mengalami gangguan jiwa bukanlah hal yang mudah terutama jika pasien tidak bisa di atur.Keluarga harus memiliki kesabaran yang tinggi merawat pasien gangguan jiwa, apalagi pelayanan kesehatan jiwa di daerah perbatasan sulit dijangkau. Menurut Sakai, (2014) dalam penelitiannya pentingnya penanganan masalah kesehatan terutama kesehatan jiwa sehingga pasien yang mengalami gangguan jiwa bisa mendapatkan pengobatan dari pihak puskesmas maupun rumah sakit.

Persepsi masyarakat atau sudut pandang masyarakat terhadap pasien yang mengalami gangguan jiwa merupakan pandangan yang negative dimana seseorang yang mengalami gangguan jiwa pasti karena dosa yang dilakukanoleh keluarganya sehingga aib masalah gangguan jiwa yang dialami disembunyikan oleh keluarga dari orang lain karena penyakit ini merupakan aib yang membuat keluarga kecewa, malu, putus asa. Kondisi ekonomi yang menghambat dapat menjadi gangguan hubungan keluarga, dalam melakukan aktivitas kesulitan financial dapat berdampak negative terhadap kesehatan keluarga.Beban psikologis dapat menggambarkan perasaan individu yang sedang merasakan kehilangan sesuatu yang berharga, merasa cemas, sedih serta malu terhadap masalah yang dialami serta meningkatnya stres dalam menghadapi gangguan perilaku akibat perubahan pola interaksi dalam keluarga (Ngadiran, 2010).

Propinsi Sulawesi Utara sendiri, khususnya di rumah sakit Jiwa Prof Dr V Ratumbuysang pada tahun 2018 diperoleh data bahwa terdapat 180 pasien rawat inap dan sebagian besar pasien mengalami gangguan jiwa berat (Skisofrenia). Pasien yang mempunyai riwayat pasung di rumah berjumlah 6 orang (Claudia, 2016).

Survei awal yang dilakukan pada tiga keluarga yang memiliki anggota keluarga dengan gangguan jiwa yang dipasung mengatakan memiliki keluarga mereka yang mengalami gangguan jiwa sangat mengganggu kenyamanan dan ketenangan lingkungan sekitar apalagi saat kambuh, yang selalu dilakukan oleh klien saat kambuh yaitu teriak pada saat warga sedang tidur malam, mencuri disiang hari dan keluyuran. Hal ini membuat keluarga khawatir dengan kenyamanan warga sekitar sehingga di lakukan pemasungan kepada klien yang mengalami gangguan jiwa dengan harapan keluarga tidak lagi merasa takut dengan perilaku yang dilakukan dan terutama kenyamanan lingkungan sekitar. Tindakan pemasungan ini dilakukan dengan cara di ikat dan di kurung didalam gubuk kecil agar klien tidak melarikan diri.

Keluarga merupakan unit terkecil dari masyarakat yang tinggal serumah serta adanya hubungan darah,perkawinan, atau adopsi. Pentingnya interaksi dalam keluarga karena keluarga memiliki peran masing-masing untuk mempertahnkan dan menciptakan suatu nilai (Friedman, 2010).

Wawancara singkat dengan keluarga yang memiliki anggota keluarga gangguan jiwa, keluarga beranggapan bahwa gangguan jiwa itu tidak bisa disembuhkan dan harus diikat demi kenyamanan bersama.Perawatan kebersihan sering dilakukan tetapi kendala yang dialami adalah tidak mau dibersihkan jika tidak dilepas ikatanya.Akan tetapi kebutuhan makan, minum dan kebersihan gubuk yang ditinggal oleh klien sering dibersihkan keluarga setiap hari.Tujuan penelitian ini yaitu menguraikan dukungan keluarga terhadap orang dengan gangguan jiwa yang di Pasung di Kecamatan Manganitu Kabupaten Kepulauan Sangihe.

\section{METODE PENELITIAN}

Penelitian ini menggunakan desain kualitatif mengeksplorasi informasi yang mendalam tentang dukungan keluarga trehadap pasien gangguan jiwa yang dipasung.Penelitian ini dilaksanakan pada bulan September 2019 di tiga kampung yang memiliki ODGJ dipasung yaitu kampung Lebo, kampung Manumpitaeng dan kampung Pinabetengan.Informan dalam penelitian ini berjumlah tiga orang, Sampel dalam penelitian, ini bukan dinamakan responden tetapi Informan.Pengambilan sampling dalam penelitian ini yaitu menggunakan teknik sampling secara Purposive Sampling dengan inklusi 1) Tidak sedang sakit fisik berat, 2) Dapat berkomunikasi dengan baik, 3) Memiliki orang dengan gangguan jiwa yang dipasung. 
Pengumpulan data dilakukan dengan wawancara mendalam dimana instrument penelitian ini adalah peneliti sendiri dalam mengembangkan pertanyaan dalam bentuk wawancara menggunakan pedoman wawancara, catatan lapangan dan recorder karena informan tidak bersedia menggunakan video kamera. Dalam penelitian ini peneliti menghargai hak azasi manusia dengan memberikan Informed consent (lembar persetujuan menjadi responden), menjaga kerahasiaan identitas informan (Anonimity) \& Confidentiality, semua informan bebas dari rasa tidak nyaman baik fisik maupun psikologis (berbuat hal yang baik), serta tidak merugikan informan selama penelitian dilakukan (Non maleficience) dan Informan mendapatkan perlakuan yang sama selama penelitian (Juztice).

Proses analisis data dilakukan dengan menggunakan tujuh metode Collaizi. Validitas data peneliti melakukan
Triangulasi dengan metode wawancara dan observasi serta triangulasi antar anggota peneliti untuk menghindari subjektifitas peneliti. Selain itu peneliti melakukan member cheking yaitu dengan validasi data hasil wawancara informan.

\section{HASIL PENELITIAN}

Informan adalah care giver yaitu yang merawat ODGJ dan merupakan salah satu anggota keluarga ODGJ, yang terdiri dari Ponakan, adik kandung dan kakak kandung. Paling muda berusia 42 tahun paling tua 65 tahun, lama merawat yang paling lama 19 tahun, semuanya berjenis kelamin perempuan dan berpendidikan SD yang tinggal di wilayah Kecamatan Manganitu kampung Lebo, Manumpitaeng dan Pinabetengan Kabupaten Kepulauan Sangihe seperti pada tabel berikut:

Tabel 1. Karakteristik Informan

\begin{tabular}{ccccc}
\hline enis Kelamin & Usia & $\begin{array}{c}\text { Pendidikan } \\
\text { terakhir }\end{array}$ & $\begin{array}{c}\text { Lama } \\
\text { merawat }\end{array}$ & $\begin{array}{c}\text { Hub dgn klien } \\
\text { (ODGJ) }\end{array}$ \\
\hline $\mathrm{P}$ & 60 & $\mathrm{SD}$ & 19 tahun & Adik kandung \\
$\mathrm{P}$ & 65 & $\mathrm{SD}$ & 12 tahun & Ponakan \\
$\mathrm{P}$ & 42 & $\mathrm{SD}$ & 10 tahun & Kakak kandung \\
\hline
\end{tabular}

Jumlah ODGJ yang dipasung adalah 3 orang setelah terjadi saturasi data.Klien ini terdiri dari 1 orang laki-laki dan 2 orang perempuan.Dukungan keluarga sangat dibutuhkan oleh klien yang mengalami pemasungan terutama semua kebutuhan sehari-hari yang dibutuhkan oleh klien sangat bergantung pada keluarga yang merawat.

Pada penelitian ini di dapatkan tiga tema besar yaitu: 1) Gejala gangguan jiwa, 2) Penyebab pemasungan dan 3) Dukungan keluarga.

\section{Tema 1:Gejala Gangguan Jiwa}

Perilaku yang terjadi pada klien awalnya di ketahui oleh informan yang merawat setelah melihat sikap klien yang berubah dan tidak biasanya.Perubahan perilaku yang nampak pada klien seperti marah-marah sampai merusak barang, bicara sendiri, suka tertawa sendiri, kurangnya perawatan diri.

“..awalnya marah-marah kong ba taria, bacerita sendiri kong makanan ja di buang kalo ada orang yang lewat depan rumah dia mo pangge bakalae, sering banting barang dirumah...pokoknya abis barang ja lempar, itu sejak $X$ stress mama meninggal"(Informan 1)

“....kadang bicara sendiri, kadang tertawa, depe perilaku so aneh noh pokoknya..mo managis le biar nda depe sebab so bataria kuat skali” (Informan 2)

“...yah bekeng rusak orang pe barang, marah-marah nda jelassampe cari masalah deng orang” (Informan 3)

Keluarga mengungkapkan bahwa perubahan sikap dan perilaku yang terjadi karena masalah pribadi yang sedang dihadapi pada klien seperti yang di ungkapkan oleh (Informan 1) perubahan perilaku terjadi karena klien stress menghadapi kepergian ibunya yang sudah meninggal. Hal ini semakin hari semakin nampak melalui perubahan 
perilaku seperti senyum sendiri, berteriak dan marah-marah tanpa sebab, bicara sendiri, perawatan diri kurang, serta membuat kekacauan pada lingkungan sekitar. Selain intu perubahan perilaku juga dialami oleh dua anggota keluarga yang lain seperti yang diungkapkan oleh (Informan $2 \& 3$ ).

Gejala gangguan jiwa ini terjadi disebabkan karena berbagai macam masalah yang dialami oleh klien itu sendiri dalam jangka waktu yang panjang. Menurut Yusuf, dkk (2015) gangguan jiwa bisa terjadi karena masalah kepribadian pasien itu sendiri sehingga kondisi fisik menjadi tanda awal pasien keluarga dapat mengetahui adanya gangguan perilaku. Pemberian dukungan secara emosional dapat membantu pasien gangguan jiwa dalam mencapai proses penyembuhan secara optimal.

Menurut Agusno (2011) dalam Purnama (2016) mengungkapkan bahwa permasalahan yang biasanya terjadi pada orang yang mengalami gangguan jiwa berasal dari tiga aspek yaitu pemahaman masyarakat yang kurang mengenai gangguan jiwa, dan bagaimana persepsi tentang masalah gangguan jiwa yang ada di masyarakat dan tidak tersedianyapelayanan kesehatan jiwa. Dengan adanya aspek ini maka kekambuhan sering terjadi kapan saja.

\section{Tema 2: Penyebab Pemasungan}

Pengambilan keputusan untuk dilakukan pemasungan kepada salah satu anggota keluarga yang mengalami gangguan jiwa, disebabkan karena sering keluyuran dan membuat lingkungan tidak aman karena perilaku klien yang membuar warga resah dan keluarga takut klien membuat masalah yang dapat merugikan orang lain. Berikut pernyataan dibawah ini:

“...dipasung karna pang bajalang kurang orang ja bilang $X$ ada disanalah, ada disinilah" (Informan 1)

“...pang bajalang kurang orang ja bilang ada dikampung sebelah, kalo so ba jalang nda ja pulang” (Informan 2)

“....nah itu tadi dipasung karna suka bekeng kekacauan di tetangga sampe so malu riki so baku ta salah deng tetangga karna depe perbuatan, babataria biar tengah malam orang da tidor kong lempar orang pe barang kase ancor, torang noh jag anti karna depe ulah itu” (Informan 3)

Dalam penelitian ini keluarga mengungkapkan tindakan yang dilakukan karena ketidaknyamanan sering terjadi baik dilingkungan keluarga maupun di rumah tetangga yang lain seperti yang di ungkapkan (I1, I2 \& I3).
Klien yang mengalami gangguan jiwa awalnya tidak akan di lakukan pemasungan akan tetapi perilaku yang semakin hari semakin bertambah parah atau kambuh membuat keluarga terpaksa melakukan pemasungan. Pemasungan ini dilakukan untuk menghindari tindakan kekerasan yang dilakukan oleh klien seperti merusak barang, membuat kekacauan di lingkungan masyarakat dan mencederai diri sendiri. Selain itu pemasungan dilakukan oleh keluarga agar keluarga bisa melakukan aktivitas sehari-hari tanpa harus waspada dengan tindakan klien yang dapat merugikan orang lain. Klien juga sering berjalan tanpa tujuan/ keluyuran, mencuri barang tetangga serta berteriak dilingkungan sehingga membuat masyarakat resah dengan kehadiran klien. Oleh sebab itu keputusan untuk melakukan tindakan pemasungan adalah cara yang tepat bagi keluarga untuk menghindari hal-hal yang dapat merugikan diri klien dan orang lain.

Pemasunganmerupakan suatu tindakan yang sangat merugikan pasien dimana anggota gerak seperti kaki dan tangan harus diikat dengan kayu atau rantai kemudian di asingkan dari tempat tinggal keluarga Keluarga dengan pasien gangguan jiwa yang dipasung seringkali merasakan beban yang berkaitan dengan perawatan pasien. Salah satu alasan pemasungan dilakukan oleh keluarga yaitu untuk mencegah pasien melakukan tindakan kekerasan yang dapat merugikan diri sendiri dan orang lain, mencegah pasien keluyurandan ketidakmampuan keluarga merawat jika pasien kambuh (Bekti, 2014).

Pemasungan yang dilakukan oleh keluarga yaitu mengikat kaki klien, mengasingkan klien dengan cara membangun pondok kecil di belakang rumah keluarga dengan jarak 5- 10 meter dengan ukurannya pondok 2x 3 meter dan 2,5x 3 meter. Kemudian tempat tinggal klien ditutup rapat dengan kayu sehingga tidak ada seorangpun yang bisa berkomunikasi dengan klien selain keluarga terdekat.Menurut Suripto (2017) ketidak tahuan keluarga tentang gangguan jiwa, merasa malu terhadap penyakit yang tidak bisa sembuh secara total, tidak adanya biaya pengobatan, dan tindakan keluaga untuk mengamankan lingkungan merupakan penyebab keluarga melakukan pemasungan kepada ODGJ. Pemasungan merupakan tindakan yang dapat merugikan pasien serta kegagalan 
keluarga dalam memberikan dukungan untuk membawa pasien mendapatkan pelayanan kesehatanjiwa. Tindakan pasung justru akan membuat kondisi pasien gangguan jiwa lebih parah lagi serta mengalami kekambuhan yang terus menerus (Yusuf, 2017).

Menurut Syarniah (2014) dalam penelitiannya mengungkapkan kebanyakan pelaku dari kasus pemasungan ini adalah keluarga dari si penderita gangguan jiwa itu sendiri.Pada umumnya keluarga tidak mengertiapayang harus dilakukan saat merawat anggota keluarga yang megalami gangguan jiwa. Keluarga merasa khawatir jika anggota keluarga mereka yang mengalami gangguan jiwa akan melakukan tindakan merusak serta berdampak pada perilaku kekerasan terhadap orang lain dan lingkungan sekitar saat pasien mengalami kekambuhan. Beban ekonomi juga menjadi salah satu penyebab sehingga keluarga tidak membawa pasien ke rumah sakit jiwa.

\section{Tema 3: Dukungan Keluarga}

Dukungan yang di berikan kepada klien dari keluarga dalam bentuk perhatian untuk memenuhi kebutuhan klien baik makan, minum dan kebersihan diri klien. Berikut pernyataan dari informan dibawah ini:

a. Dukungan instrumental

“...yang penting rajin no mo sebersih, mo kase bersih-bersih depe rumah kecil itu deng semandi” (Informan 1)

“....mo semandi, ganti depe baju, biar cuma kukis dari pasar ada itu kita ja simpan” (Informan 2)

“...setiap hari torang ja urus pa X...kase makan, mandi deng kalo torang makan enak, ja kase le pa X nda ja bedakan biar so saki bagitu" (Informan 3)

b. Dukungan informasional

"...Ja kase tau musti minum obat supaya bae deng nda mo dikurung terus kalo rajin minum obat” (Informan 2)

“...so pernah lalu niat mo bawa ke puskesmas mar nimau mo diobat” (Informan 3)

c. Dukungan emosional

“...kase semangat, selalu kita ja bilang paka sehate ko ikau supaya dang mo sama deng dulu” (Informan 1)

“....kadang kalo so mo kambuh kita ja pi bilang sudah jo mo bataria, berdoa kong manyanyi jo lagu rohani supaya nda ada setang mo suru babataria bagitu” (Informan 3)

“....berdoa semoga depe saki ini cepat bae kasiang, kita ja bilang ngana pasti bae asal semangat”(Informan 2)
Dukungan yang diberikan oleh keluarga berbedabeda pada klien baik itu motivasi, dorongan untuk minum obat, doa dan kebutuhan makan minum dan pakaian yang diberikan untuk memenuhi kebutuhan klien setiap hari. Menurut (Sefrina 2016 dalam Fridman 2010) dukungan emosional merupakan fungsi afektif keluarga yang harus diterapkan kepada seluruh anggota keluarga termasuk individu dengan skizofrenia. Fungsi afektif berhubungan dengan fungsi internal keluarga yaitu dengan memberikan perlindungan serta dukungan psikososial pada anggota keluarga yang sakit, karena keluarga juga sebagai sumber utama dari cinta dan kasih sayang.

Keluarga memiliki peran yang sangat penting termaksud dalam memenuhi kebutuhan klien dalam menyediakan pakaian, makan dan minum.Keluarga adalah sumber bantuanpraktis bagi pasien dalam pemenuhankebutuhannya.Salah satu bentuk dukungan keluarga adalah dengan rutin mengambil obat ke pelayanan kesehatan jiwa seperti rumah sakit.Keadaan ini terjadi karena pasien tidak mampu untuk mengambil obat secara mandiri.Dukungan dari keluarga besar dan kerabat terdekat sangat membantu keluarga dalam pengambilan obat di pelayanan kesehatan.Membantu mengambilkan obat secara rutin di rumah sakit juga merupakan bentuk dukungan yang diberikan keluarga.Bantuan ini diberikan karena ketidak mampuan klien untuk dapat pergi sendiri ke pelayanan kesehatan, namun waktu dan tenaga untuk mengambil obat di rumah sakit dilakukan oleh keluarga (Yusuf, 2017).

Wuryaningsih (2013) kepedulian keluarga dilakukan dengan memotivasi, menjadi pendengar yang baik, membuat senang, memberi kesempatan rekreasi, memberikan tanggung jawab dan kewajiban peran dari keluarga sebagai pemberi asuhan. Keluarga berperan penting dalam memberikan dukungan selama proses pengobatan dan patuh minum obat sehingga mencapai kesembuhan.

Menurut Yusuf (2017) dalam penelitiannya menyebutkan bahwa dukungan penilaian yang diberikan apabila keluarga tersebut mengetahui serta memahami bahwa anggota keluarga yang mengalami gangguan jiwa, membutuhkan bantuan dalam memenuhi kebutuhan setiap 
hari dan pengobatannya. Keluarga berpendapat bahwa gangguan jiwa yang dialami oleh anggota keluarga mereka disebabkan oleh roh jahat sehingga pasien klien mengalami kesurupan sehingga anggapan bahwa orang yang mengalami gangguan jiwa bukanlah orang baik-baik, dan hal ini menjadi salah satu penghambat keluarga dalam memberikan dukungan. Tindakan pemasungan dapatmenyebabkan keterbatasan gerak pada pasien sehinggapemenuhan kebutuhan dasar seperti pemeliharaan kesehatan, mendapatkan pendidikan serta pekerjaanpun mengalami hambatan akibat pemasungan (Halida, dkk 2016).

Dukungan dalam bentuk apapun yang diberikan keluarga sangat mempengaruhi kesembuhan orang yang mengalami gangguan jiwa. Menurut Yusuf (2017) dalam penelitiannya mengatakan situasi keluarga yang memberikan dukungan emosional akan membantu pasien untuk mencapai penyembuhan dengan optimal dimana sikap empati dan rasa percaya dari keluarga sangat dibutuhkan oleh pasien untuk mencegah kekambuhan.

\section{KESIMPULAN}

Gangguan jiwa tidak bisa disembuhkan secara total dengan jangka waktu yang pendek akan tetapi bisa mengurangi kekambuhan tanpa harus dipasung. Walaupun dalam keadaan dipasung tapi keluarga terus memberikan dukungan kepada klien baik itu dukungan instrumental, dukungan informasional dan dukungan emosional.Tanpa dukungan keluarga kekambuhan mudah terjadi kepada klien dengan gangguan jiwa.

\section{DAFTAR RUJUKAN}

Bekti Suharto. 2014. Budaya Pasung dan Dampak Yuridis Sosiologis (Studi Tentang Upaya Pelepasan Pasung dan Pencegahan Tindakan Pemasungan di Kabupaten Wonogiri), (online) IJMS - Indonsian Journal on Medical Science - Volume 1 No 2 - Juli 2014 ,

http://ejournal.ijmsbm.org/index.php/ijms/article/vie $w / 21 / 21$.

Collaizi, P. 1978. Psichological research as the phenomenologist views it. New York: Oxford University Press.
Creswell, J.W. 2012.Planning, Conducting, and Evaluating Quantitative and Qualitative Research. (online) https:// doi.org/10.1017/CBO9781107415324.04

Friedman, M.M. 2010. Buku Ajar Keperawatan Keluarga: Riset, Teori dan Praktik. Edisi 5. EGC: Jakarta

Claudia R.A 2016 pengaruh pemberian Pendidikan Kesehatan tentang pencegahan pasung terhadap pengetahuan dan sikap kader kesehtan di desa Mancasan.

Halida, N., Dewi, E. I., \& Rasni, H. 2016.Pengalaman Keluarga dalam

Claudia. (2016). PemenuhanKebutuhan Perawatan pada Orang DenganGangguan Jiwa (ODGJ) dengan Pasungdi Kecamatan Ambulu Kabupaten Jember. (online)e-Jurnal Pustaka Kesehatan, 4(1), Januari,78-85.

Ngadiran, A. 2010.Studi Fenomenologi Pengalaman Keluarga Tentang Beban dan Sumber Dukungan Keluarga dalam Merawat Pasien Halusinasi. (online) Program Magister Keperawatan Jiwa: FIK UI. https://ejornal.lib.ui.ac.id

Nihayati, H.E, Mukhalladah D, Krisnana, I. (2016). Pengalaman Keluarga Merawat Klien Gangguan Jiwa Pasca Pasung. Jurnal Ners Vol. 11 No. 2 Oktober 2016: 283-287. https://ejournal.unair.ac.id/JNERS/article/view/2988

Purnama, G. 2016.Gambaran stigma masyarakat terhadap klienGangguan jiwa di RW 09 desa Cileles Sumedang.Jurnal Pendidikan Keperawatan Indonesia. (online) Vol.2 No. 1 Juli 2016.http://ejournal.upi.edu/index.php/JPKI

Riskesdas, 2018.Badan Penelitian dan Pengembangan Kesehatan. 2018. Laporan Nasional 2018, 1384.Kesehatan KementerianKesehatan Republik Indonesia.

Sakai, C., Mackie, T., Shetgiri, R., Partap, A., Flores, G., Leslie, L. 2014. Mental Health Beliefs and Barriers to Accessing Mental Health Services in Youth Aging out of Foster Care.Academic Pediatrics, 14(6), 565-573. (online) https://doi.org/10.1016/j.acap.2014.07.003

Suripto dan Siti Alfiah, Indonesia Bebas Pasung 2017.(Pemodelan Inovasi Pemerintah Daerah Menuju Bebas Pasung). (online) http://inovasi.lan.go.id/uploads/download/148723 9697 BSIAN-Vol.-1-(fix).pdf. Diakses pada tanggal 10 April 2019. 
Syarniah, Rizani, A., Sirait, E. .2014.“Studi deskriptif persepsi masyarakat tentang pasung pada klien gangguan jiwa berdasarkan karakteristik demografi di desa Sungai Arpat Kecamatan Karang IntanKabupaten Banjar", Jurnal Skala Kesehatan Volume 5 No. 2 Tahun 2014, (online) https://ejurnalskala kesehatanpoltekkesbjm.com.Diakses pada tanggal 11 April 2019 pukul 19.00

Wuryaningsih et al,. (2013) Studi fenomenologi: pengalaman keluarga mencegah Kekambuhan perilaku kekerasan pasien Pasca hospitalisasi RSJ. Journal Keperawatan Volume 1, No. 2, 178-185
Yusuf, A., Fitryasari, R., \& Nihayati, H. E. 2015. Buku Ajar Keperawatan KesehatanJiwa. Jakarta: Penerbit Salemba Medika. Chandra, L.S. (2004). Schizophrenia Anonymous, A Better Future.Jakarta: Widyatama

Yusuf,.A., Tristiana, D. 2017 Fenomena Pasung dan Dukungan Keluarga terhadap Pasien Gangguan Jiwa Pasca Pasung. (online), Volume 5 Nomor 3. http:// jkp.fkep.unpad.ac.id. Jurnal Keperawatan. 